\title{
New trends and competition in the market of higher education services in the context of digitalization
}

\author{
Galina V. Astratova ${ }^{1,2, *}$, Tatyana K. Rutkauskas ${ }^{1}$, Natalya V. Parushina ${ }^{3}$, and Natalya A. \\ Suchkova ${ }^{3}$ \\ ${ }^{1}$ Ural Federal University named after the first President of Russia B. N. Yeltsin, Yekaterinburg, \\ Russia \\ ${ }^{2}$ Ural Juridical Institute of MIA of Russia, Yekaterinburg, Russia \\ ${ }^{3}$ Orel State University of Economics and Trade, Orel, Russia
}

\begin{abstract}
The aim of the study was to analyze new trends, competition and structural changes in higher education in the context of digitalization. The main directions of higher education development in the XXI century are identified. It is shown that by 2020 , new trends in the market of higher education services have appeared and fully manifested themselves, due to three key factors: 1) increased global competition; 2) the active introduction of digital technologies in higher education; 3) the impact of the global COVID pandemic on educational technologies. It is shown that the coronavirus pandemic was a powerful incentive for the transition to digital technologies in higher education. Thanks to digitalization, the structure of the market has changed, and the number of players has increased significantly, and the market consists of private and public institutions, ministries of education and government agencies, educational, consulting and test (rating) companies, etc. Moreover, the global competition of universities for quality is becoming more organized and technically equipped; it increasingly relies on impersonal methods of assessing quality using digital technologies. At the same time, the authors draw a number of conclusions about the negative consequences of distance education. It is shown that competitiveness and accessibility of educational services for different categories of citizens in the difficult conditions of global challenges and threats, the wave pandemic, is ensured through highquality interaction of all participants in the process, the activity of scientists and practitioners around the world, and state support for teaching initiatives in all regions of the country.
\end{abstract}

\section{Introduction}

The outbreak of the coronavirus pandemic and its rapid spread around the world speaks of the vulnerability of human civilization to previously unknown, new diseases. It is also important that the pandemic occurred in the context of the global trend of digitalization of

\footnotetext{
*Corresponding author: galina_28@mail.ru
} 
the economy. Accordingly, the response measures taken by the governments of the countries have led to serious changes in the socio-economic development of the regions, and the acceleration of the processes of digitalization of the economy has occurred mainly in developed countries.

The higher education system was in a special position in these conditions.

Indeed, the processes of globalization and digitalization, the ubiquitous spread of information and computer technologies, have led to changes in both the higher school itself (the "networking" of universities) and the learning process. For example, today, for universities that position themselves not only locally, but also internationally, the presence of an "online presence" is mandatory. In the new conditions, the methods of teaching and attracting new students, the nature of the work of the teaching staff, etc., are changing [9, 32].

Finally, the COVID-19 virus pandemic has illustrated the global need for online competencies for the majority of workers in the labor market, as well as the fact that in modern realities, it is almost impossible to implement higher education services without access to the Internet $[2,21,34]$.

At the same time, as we noted earlier [2], in terms of the speed, nature, models of digital technologies and the results of the transition to online education, Russia is significantly behind both the pace and nature of the development of online education in the United States, the EU, China, and other countries, and the real needs of our country's economic development.

In addition, the process of developing a strategy for the development of higher education in Russia in the context of new global trends and structural changes in the context of digitalization is a very controversial and debatable event, which includes not only the coordination of various interests of the subjects of the education market, but also economic and mathematical modeling, assessment of the effectiveness of resource management, and a number of other problems.

In this regard, the purpose of the study was to analyze new trends, competition and structural changes in higher education in the context of digitalization

\section{Materials and methods of research}

The main research tools used in this work are system analysis. For the study of theoretical and practical material, the methods of desk research, the principles of formal logic, synthesis, statistical, logical methods of analysis, as well as methods of comparison, generalization of the experience of foreign and domestic higher education, structuring, based on the processing of a large volume of factual material, are used.

\section{Digitalization and new trends in the development of higher education}

One of the priority directions of Russia's development [8] and most of the world's economic leaders (USA, UK, Germany, China, etc.) [13] is the formation of the digital economy. The foundation of the digital economy is modern digital technologies, which have turned from a separate technological industry into a new way of life that affects all types of human activities.

The most obvious consequence of access to the Internet has been the explosive growth in the production and consumption of information around the world. So, according to the World Bank Report [4, 38], "a typical day on the Internet" represents \$ 207 billion e-mail 
messages; 8.8 billion video views on YouTube; 4.2 billion search queries in Google; 36 million purchases in Amazon, etc.

The new, digital way of life is represented today by at least ten key areas of activity:

1. $5 \mathrm{G}$ Internet;

2. Electric cars and self-driving cars;

3. 3D-printing;

4. Artificial intelligence and Big Data;

5. Virtual (VR) and artificial (AR) reality;

6. Cloud data storage;

7. Internet of Things;

8. Quantum computing;

9. Blockchain;

10. Brain implants [15].

However, as noted in the World Bank Report [4, 38], the benefits of digital transformation of the economy are inferior to the pace of the spread of digital technologies (especially the Internet, mobile technologies and other devices for collecting, storing, processing, analyzing and exchanging information in digital form). To date, digitalization from the simple introduction of technologies in the business models of individual companies has transformed into a global process of transition to the digital economy, where the processing and analysis of digital data not only increases the efficiency of business processes, but also becomes a key factor in the development of society.

A special place in the digital economy is given to education in general and higher education in particular. This is due to the fact that in the XXI century in developed countries, higher education, together with the R\&D (Research and Development) sector, is becoming the largest sector of the global services market. Thus, according to the WTO [39], in 2019, global trade in services amounted to $\$ 13.3$ trillion. At the same time, only from 2005 to 2017, the world trade in commercial services increased significantly, broken down by sector [39, p. 25]:

$>$ telecommunications, computer and audio-visual services by $13.2 \%$;

$>$ Research and Development (R\&D) by $1.4 \%$;

$>$ educational services by $0.8 \%$.

At the same time, one of the fastest growing sectors of the global education market ( $+23 \%$ annually in the period from 2012 to 2017 ) is digital education, although its share in the total volume of the educational services sector before the coronacrisis was not large: less than $3 \%$ [12].

Moreover, in 2008, the global market for higher education services was $\$ 100$ billion [1]. According to experts, its value may grow to $\$ 600-800$ billion by 2030 [36]. The United States, Great Britain, Canada, Australia and other developed countries are leading in this market, where higher education services are developing mainly as an export industry $[6,14]$. It should be noted that the total income from the Russian export of educational services is also growing. For example, only from 2007 to 2015 the growth from sales of educational services abroad increased by 1.64 times (in US\$) and 3.28 times (in rubles) [7]. At the same time, the share of the Russian Federation is, according to various estimates, no more than $7 \%$ of the world market of higher education services (if we exclude representatives of the CIS from the total number of foreign students studying in Russian universities, then Russia's share in the global market of higher education services will not exceed $2 \%$ ).

We consider it necessary to emphasize that education has traditionally been considered a conservative industry, subject to slow and smooth changes over a long time. At the same time, scientific and technological progress, changes in the productive forces and industrial relations in the XX century, and especially in the first quarter of the XXI century, led to 
changes in society and, accordingly, influenced the fact that the market for higher education services has changed several mainstream trends only in the last few decades.

First, by the end of the last century, as noted in our earlier studies [3, pp. 22-23] and according to the results of research by other scientists and practitioners $[1,6,14$, et al.], the following main changes occurred:

1) Rapid growth of the scale of the educational services market:

2) Increasing mass market of educational services market and ensuring the right to education for everyone (the opportunity and equal chances for everyone to get an education in an educational institution of any type, regardless of national or racial affiliation);

3) Diversification of the territorial structure of the educational services market and the emergence of new "players";

4) Globalization and internationalization of higher education, based on the comprehensive nature of knowledge and the mobilization of the collective efforts of the international educational and scientific community;

5) Universalization of the content of all types of education, which cannot be stopped in the era of the information revolution and the spread of the Internet;

6) Democratization of the education system and the accessibility of education to the entire population of the country, the continuity of its stages and levels, the provision of autonomy and independence to educational institutions;

7) Increasing the range of educational and organizational activities aimed at both satisfying diverse interests and developing students ' abilities;

8) Turning education into a priority object of financing in the developed countries of the world;

9) Cross-cultural integration, tolerance to different cultures, traditions and customs; etc.

In Russia, at the same time, there is an educational reform, during which the following factors have a significant impact on the market of higher education services: 1) introduction of the Unified State Exam (USE), 2) transition to a multi-level system of higher education, 3) introduction of multi-channel financing of education, 4) reduction of the teaching staff, 5) consolidation of universities. These questions are discussed in more detail in our previous study [3, pp. 22-23].

Secondly, by 2010-2019, the emphasis on the market of higher education services is shifting somewhat, and the key trends, according to the results of our earlier studies [2] and conclusions from the results of research by other scientists and practitioners $[10,26,37$, etc.], are the following phenomena:

1. Changing global demographics due to increased life expectancy and declining birth rates (Africa alone is the only region where the youth population will grow until 2025) [37];

2. Increasing access to education for everyone, although there are still problems of gender and class inequality;

3. Development of national strategies for the internationalization of education, including, inter alia, the involvement of foreign students for training, as well as highly qualified migrants for conducting educational programs in universities;

4. Strengthening multi-sector cooperation, which implies not only the development of cooperation between universities and industrial enterprises, but also cooperation in the field of international higher education and science, R\&D (for example, virtual international internships on the EU-VIP, PROVIP platforms. Pathway, etc.);

5. Use of new educational technologies. There are two main tools of educational technologies in universities: a) online learning and b) technologies that affect teaching, learning, and administration. As technologies (Internet of Things, blockchain, 3D printing, adaptive technologies, mobile technologies, etc.) [43] continue to integrate into the real world, changing and transforming it, higher education should also change over time and 
integrate educational technologies that contribute to the development of international higher education;

6. Growing demand for specific competencies and skills, due to the fact that with the future automation of workplaces, there will also be a radical transformation of the labor market and the market of educational services. Accordingly, universities will have to change the educational programs in such a way as to guarantee graduates the appropriate competencies and skills;

7. Strengthening the influence of the English language. Although many persons consider English as a means of international business communication, but English as a way to attract foreign students for international higher education plays a much greater role, and this role is only growing every yea.

Third, by 2020, new trends in the market of higher education services have emerged and fully manifested themselves. These trends are related to three key factors, in our opinion: 1) increased global competition; 2) the active introduction of digital technologies in higher education; 3 ) the impact of the global COVID pandemic on educational technologies. We considered it appropriate to focus on the problems of global competition in this article.

\section{Strengthening of global competition in the market of higher education services}

Speaking about the problem of increasing global competition, it should be noted that competition in the education market is very high. First, thanks to digitalization, the market structure has changed, and the number of players has increased significantly. For example, only in Russia can we count at least nine key players in the education services market, including: schoolchildren, students, language platforms, aggregators, programmers, etc. [12].

Secondly, the structure of the higher education market has also changed dramatically over the past two decades.

As noted in the report of Transparency Market Research [28], the number of players in the global market for higher education services is increasing. Now it consists of private and public institutions, ministries of education and government agencies, educational, consulting and test (rating) companies, etc. Here is a list of key players in today's global higher education market: Smart Technologies, Inc.; Xerox Corporation; Panasonic Corporation; Oracle Corporation; EduComp Solutions; Dell Inc.; Cisco Systems Inc.; Three River Systems; IBM; Blackboard Inc.; Adobe Corporation; and others.

Accordingly, educational institutions are becoming increasingly receptive to the introduction of digital technologies, which play an important role in education, allowing students and teachers to interact and take advantage of the new learning opportunities that open up. It should be noted that in the market of higher education services, competition is growing not only between public and private universities. In order to attract students and teachers from all over the world, universities must, in addition to participating in international rankings, attract business partners, associations and foundations, both to conduct research and to find sources of funding [28].

Today, higher education institutions are characterized by economic competition in a tough global market environment, where governments are no longer key players $[18,28]$. Thousands of universities from one and a half hundred countries offer their services, although the main struggle for the consumer is among the United States, Canada, Great Britain, Germany, France, Australia, and Japan, where more than $80 \%$ of all international students study $[4,22,23]$.

As many researchers note $[18,19,20,27,31,33]$, over the past twenty to thirty years, the global system of higher education has dramatically changed not only the forms, types 
and patterns of competition (from the struggle for the number of students to the struggle for the amount of budgets and the number of best professors), but also the intensity of competition. This eventually led to the emergence of new forms of competition-especially where these changes appeared, developed and were strongest, i.e. in research universities in the United States and Europe. It is argued that competition in higher education is no longer just between individuals, universities, and countries. Competition has become institutional and global, which has led to a multi-level form of competition and the transformation of universities into full-fledged business competitors.

In particular, since the $60 \mathrm{~s}$ of the last century, in the United States, the editors of US News decided to invest in educational ratings as a way to distinguish themselves from competitors, offering society "news that can be used" in marketing strategies [24]. Since that time, the rankings have been published annually. In particular, at the moment the most well-known lists are the following: THE, QS, ARWU, etc. For many years, the top ten universities in the world are universities from the United States and Great Britain (Table 1).

Table 1. The "Top ten" of the best universities in the world and the "top ten" of the best Russian universities in the world university ranking in 2021, according to THE (Times Higher Education) [40]

\begin{tabular}{|c|c|c|c|c|c|}
\hline Rating & Name, country, region & $\begin{array}{l}\text { Number of } \\
\text { students, } \\
\text { total }\end{array}$ & $\begin{array}{l}\text { Number of } \\
\text { students per } \\
1 \text { teaching } \\
\text { staff }\end{array}$ & $\begin{array}{c}\text { Number of } \\
\text { international } \\
\text { students }\end{array}$ & $\begin{array}{l}\text { Ratio of } \\
\text { women } \\
\text { to men }\end{array}$ \\
\hline 1. & University of Oxford, UK & 20774 & 11,1 & $41 \%$ & 46: 54 \\
\hline 2. & Stanford University, USA & 16223 & 7,4 & $23 \%$ & 44: 56 \\
\hline 3. & Harvard University, USA & 21261 & 9,3 & $25 \%$ & $49: 51$ \\
\hline 4. & $\begin{array}{c}\text { California Institute of Technology, } \\
\text { USA ( }\end{array}$ & 2238 & 6.3 & $33 \%$ & $36: 64$ \\
\hline 5. & $\begin{array}{c}\text { Massachusetts Institute } \\
\text { of Technology, USA }\end{array}$ & 11276 & 8,4 & $34 \%$ & 39: 61 \\
\hline 6. & University of Cambridge, UK & 19370 & 11,0 & $38 \%$ & 47: 53 \\
\hline 7. & $\begin{array}{c}\text { University of California, Berkeley, } \\
\text { USA }\end{array}$ & 39918 & 19,8 & $17 \%$ & 51: 49 \\
\hline 8. & Yale University, USA & 12910 & 6,0 & $20 \%$ & 50: 50 \\
\hline 9. & Princeton University, USA & 8091 & 8,0 & $23 \%$ & $46: 54$ \\
\hline 10. & University of Chicago, USA & 4292 & 5.9 & $31 \%$ & 46: 54 \\
\hline$\ldots$ & & & & & \\
\hline 174. & Moscow State University, Russia & 28525 & 8,4 & $32 \%$ & 52: 48 \\
\hline $\begin{array}{l}201- \\
250\end{array}$ & $\begin{array}{l}\text { Moscow State University of Physics } \\
\text { and Technology, Russia }\end{array}$ & 5736 & 11,4 & $18 \%$ & $25: 75$ \\
\hline $\begin{array}{c}201- \\
250 \\
\end{array}$ & Ural Federal University, Russia & 26807 & 12,9 & $13 \%$ & 48: 52 \\
\hline $\begin{array}{l}251- \\
300\end{array}$ & $\begin{array}{c}\text { Higher School of Economics, } \\
\text { Russia }\end{array}$ & 25268 & 14,8 & $11 \%$ & н / д \\
\hline $\begin{array}{c}301- \\
350\end{array}$ & $\begin{array}{l}\text { Peter the Great Saint Petersburg } \\
\text { Polytechnic University, Russia }\end{array}$ & 16768 & 9,2 & $31 \%$ & 39: 61 \\
\hline $\begin{array}{c}401- \\
500\end{array}$ & $\begin{array}{c}\text { National Research Nuclear } \\
\text { University, Russia }\end{array}$ & 5797 & 10,5 & $26 \%$ & $34: 66$ \\
\hline $\begin{array}{c}501- \\
600\end{array}$ & $\begin{array}{c}\text { Saint Petersburg State University of } \\
\text { Information Technologies, } \\
\text { Mechanics and Optics, Russia }\end{array}$ & 10094 & 14,5 & $17 \%$ & $36: 64$ \\
\hline $\begin{array}{l}601- \\
800\end{array}$ & $\begin{array}{c}\text { National University of Science and } \\
\text { Technology, Russia }\end{array}$ & 7168 & 10,8 & $26 \%$ & 40: 60 \\
\hline $\begin{array}{c}601- \\
800\end{array}$ & $\begin{array}{c}\text { Novosibirsk State University, } \\
\text { Russia }\end{array}$ & 7043 & 6,2 & $20 \%$ & н / д \\
\hline $\begin{array}{c}601- \\
800\end{array}$ & Kazan Federal University, Russia & 25940 & 9,7 & $25 \%$ & 68: 32 \\
\hline
\end{tabular}

As follows from the data of THE, no more than 50 Russian universities are included in this rating and are far from being in the leading positions. The annual leader in this list is 
only Lomonosov Moscow State University, which is included only in the top 200 ranking of the best universities in the world.

Global competition between universities takes place in the form of a competition for quality, where the main indicators are the following [40, 41]: forms of education, international cooperation, multi-channel funding (primarily extra - budgetary), R\&D volumes, citation indexes, etc.

In fairness, it should be noted that different models of cultures and traditions of higher education still exist in different countries. However, in reality, universities around the world take a hybrid approach, where all the well-known university traditions interact with each other. At the same time, there are some universities that still retain the reputation and traditions of a certain model, and to some extent this tradition distinguishes them from all others [30]. However, it is not the purpose of our study to analyze these trends.

Thus, competition for quality among universities (and especially research universities) turns from competition for resources (budget, students and staff) into competition for status (image, reputation, citation), which ultimately affects resources as well $[19,33]$.

For example, competition to attract talent from all over the world is growing very quickly, as more and more countries offer additional positions to graduates and postgraduates for non-residents of the country and, as a rule, with higher wages compared to citizens of the country $[17,30]$. Moreover, fast-growing economies like China and Singapore are investing heavily in developing their higher education systems and making them friendlier to talented people from all over the world. In addition, the advent of new technologies has changed the traditional model of higher education, where physical presence is no longer a requirement $[30,42]$.

Competition for attracting finance is also growing. Although the distinctive feature of the Russian online education market is the initial focus on paid models, while in the United States both paid and free online university courses existed and developed in parallel, but in general, Russia is very much inferior in terms of the share of education spending in GDP. So, in 2016, public and private spending on educational institutions, as a \% of GDP, was the following:

$>$ In OECD countries $-5,0 \%$;

$>$ In USA - 6,0\%;

$>$ In Russian Federation - 2,4\% [12].

In this regard, within the framework of the national project of the digital economy of Russia [8], experts of the HSE conducted experimental calculations of the internal costs amount for the digital economy development, based on available statistical information. As a result, the composition and amount of costs for the digital economy development were identified, and proposals for changes in the federal statistical observation were developed. It is shown that spending on the digital economy development (including in education) will grow exponentially in the near future [13].

Accordingly, the global competition of universities for quality is becoming more organized and technically equipped; it increasingly relies on impersonal methods of assessing quality using digital technologies, such as $[11,16,25,26,29,37]$ : Internet of Things, blockchain, cybersecurity, augmented and virtual reality, Big Data, artificial intelligence and machine learning, universal accessibility, etc. New digital technologies are used to carry out the following operations and procedures in the fight for quality: various forms of accreditation and rating of universities, competitive selection of teaching staff, scientometric assessments of publications, awarding of scientific grants, etc. For example, the association of the university name (or name of the university professor) with a highstatus grant (for example, with the grants of the European Research Council - ERC in Europe, or TÜBITAK in Turkey, or NSF in the USA, etc.) increases the personal status, as 
well as the status of the educational institution, since the above grants are now an indicator of the academic quality of the university and/or professor.

Studies by various authors have shown that this growing form of competition has given rise to new classifications and categories. Moreover, at the same time, there are unions of participants belonging to the same category (for example, leagues, guilds, or university associations), whose cooperative behavior allows for various forms of benefits and, accordingly, contributes to the sustainability of these alliances [33].

Ultimately, the increasing competition in modern conditions also leads to the complication of the university management process. This also leads to the need to use various digital technologies $[11,16,25,26,29,37$, etc. $]$ in order to automate the processes of collecting, processing, storing and analyzing heterogeneous external and internal information, as well as to translate communication between divisions (institutes and departments), teaching staff and employees, partners, contractors and customers into electronic form.

It should be noted that the coronavirus pandemic has undoubtedly been a powerful impetus for the transition to digital technologies in education. As noted above, all subjects of the educational process had to urgently master distance learning.

At the same time, our educational practice shows that there are a number of negative consequences of distance learning during the pandemic: 1) digital technologies free the student from the main type of his activity - mental work; 2) analysis of independent work of students indicates that screen addiction contributes to illiteracy; 3) typing more on the computer, there is a loss of writing skills, which contributes to the loss of creative abilities; 4) communication with the computer slows down the development of students, there are problems with the expression of thoughts both orally and in writing; et al.

The problems that arose in the educational process at the beginning of the pandemic, such as technical, questions of the organization of the educational process, psychophysiological, and a year later did not lose their relevance, but their order and content changed. Due to innovative equipment and technologies, problems of a psychophysiological nature have come to the fore, technical and methodological problems have moved to the background. At the same time, there is a need for third-party services to enhance interactivity, which requires further restructuring of the distance learning process.

Digital technologies open up the horizons of large-scale changes in higher education, both in terms of opportunities for improving the educational system, and in terms of the need for fundamental modernization of business processes, organizational design, and the development of the potential of teachers. Many educational services will be digitalized, and related technologies that regulate and optimize the educational process will be developed.

\section{Conclusion}

In the context of the global processes of the post-industrial way of life, the digital economy, the productive forces and production relations in all markets are radically changing, but especially noticeably in the higher education system.

Classes at universities take place in a remote format, the latest achievements of digital technologies are used and new educational technologies are emerging. Meanwhile, today the situation in the market of higher education services has worsened due to the challenge of Covid-19 on a global scale, which has affected all areas of socio-economic development of all regions of the world, and, above all, the Russian Federation.

The widespread use of remote technologies in the educational sphere with the simultaneous involvement of the population of different ages in obtaining educational services dictates the need to include in the educational programs courses that would be aimed at mastering modern technologies, internet outlets, information access portals, 
electronic platforms for communication interaction. We are sure, in order for Russia to become a world leader in the development of digital technologies, the availability of information services should be free and online for all universities in the country. Moreover, it is important that educational information courses include both the basic development of practical skills to use the Internet, and professional skills to work with specialized resources and programs.

The development of the labor market, the threat of a second wave of the COVIDepidemic, and the systematic monitoring of the ranking of the most popular professions on Russian and global recruitment portals confirm the need to expand the flexibility of higher educational organizations in offering professional programs. The individual educational trajectory should be built not only at the stage of choosing a profession or in the process of mastering it at the training stages, but also in the possibility of offering universities a set of professional programs of additional education. These programs should be available to students and trainees, both on a paid and free basis, to our mind. Moreover, the availability of programs can be realized through grant support, joint global national projects and funds from the national projects "Demography", "Education", "Science", "Small and Mediumsized enterprises". In the context of digitalization of education, programs are implemented on digital educational platforms known to a wide range of students, or in cloud services.

The emphasis on practical training in the direction of the development of professional education should be placed on the exit of students and listeners outside the classroom. This is not only the expansion and equipment of practice-oriented laboratories and youth laboratories of production startups on the university campus, but also the constructive interaction of young people with mentors and specialists in production laboratories that are created at enterprises. A virtual, augmented reality and digital business model will allow you to join the production process and the value chain of the product on-line under the supervision and advice of a mentor. Practical training, thus, will meet its intended purpose and will allow getting a direct economic and educational effect from new studies in the digital educational space.

The competitiveness and accessibility of educational services for different categories of citizens in the difficult conditions of global challenges and threats, the wave pandemic, is ensured through high-quality interaction of all participants in the process, the activity of scientists and practitioners around the world, and state support for teaching initiatives in all regions.

\section{References}

1. I.A. Aydrus, V.M. Filippov, World market of educational services, 194 (2008)

2. G.V. Astratova, World of Science. Pedagogy and Psychology, 3, 17 (2020)

3. G.V. Astratova, Science of Science, 4, 27 (2016)

4. World Bank. 2016 year. World Development Report 2016 Digital Dividends. Overview. World Bank, Washington DC. License: Creative Commons Attribution CC BY 3.0 IGO, https://openknowledge.worldbank.org/.

5. World Education Report. Comparison of world statistics in the field of education (2007) http://www.ifap.ru/

6. V.A. Galichin, International market of educational services: main characteristics and development trends (2015)

7. I.G. Korotkov, V.A. Zubenko, World of new economy, 3, 14 (2017)

8. Program "Digital Economy of the Russian Federation". Approved by the order of the Government of the Russian Federation dated July 28, 2017 No. 1632-r. 
9. Russian education - 2020: a model of education for a knowledge-based economy: to the IX Intern. scientific. conf. "Modernization of the economy and globalization", Moscow, April 1-3, 2008, ed. J. Kuzminova, I. Frumin; State un-t - Higher School of Economics. - M .: Ed. House of the State University Higher School of Economics, 39 (2008)

10. T.V. Semenova, K.A. Vilkova, I.A. Shcheglova, Education Issues, 2 (2018)

11. M. A. Sklyar, K.V. Kudryavtseva, Economic revival of Russia, 3(61), 103 (2019)

12. Trends in the development of the online education market (2017), https://www.marketing.spb.ru/

13. G. I. Abdrakhmanova, K. O. Vishnevsky, L. M. Gokhberg, Trends, competencies, measurement: reports. to XX Apr. international scientific. conf. on the problems of economic and social development, Moscow, April 9-12 (2019)

14. E.N. Shcherbak, World market for higher education (2009)

15. 10 key technologies of the last decade (2020), https://habr.com/

16. J. Ainslee, Digitization of Education in the 21st Century (2018) https://elearningindustry.com/

17. M. Barber, K. Donnelly, S. Rizvi, L. Summers, An avalanche is coming: Higher education and the revolution ahead (2013)

18. J, Brennan, Ten Years on: changing education in a changing world. Center for Higher Education Research and Information, Open University Press, Maidenhead, UK, 23 (2004)

19. N. Brunsson, L. Wedlin, Competition for Status: The Example of Universities, Communication at the Competition(s) Workshop at the Copenhagen Business School, for the 'Performances of Value: Competition and Competitions Inside and Outside Markets' project, supported by the Leverhulme Trust and led by David Stark (2016)

20. N. Brunsson, K. Sahlin-Andersson, Organization Studies, 21, 721 (2020)

21. Ceylan Rahmiye Figen, Ozkan Burhan, Mulazimogullari Esra, The European Journal of Health Economics (2020)

22. Education at a Glance 2016. OECD indicators, OECD publishing, http://www.keepeek.com/

23. Education at a Glance 2019. OECD indicators, OECD publishing, https://www.oecdilibrary.org/

24. W. Espeland, The World of Indicators: The Making of Governmental Knowledge through Quantification, 56 (2015)

25. D. Fedirko, 8 Top Trends Of Digital Transformation In Higher Education. 24 March. (2019) https://elearningindustry.com/

26. Gilbert Nestor, 19 Higher Education Trends for 2020/2021: Latest Forecasts To Watch Out For, https://financesonline.com/

27. R. Hasse, G. Krücken, Sociologia Internationalis, 51, 181 (2013)

28. Higher Education Market - Global Industry Analysis, Size, Share, Trends, Analysis, Growth and Forecast 2016 - 2023, https://www.transparencymarketresearch.com/

29. S. Kamsker, G. Janschitz, S. Monitzer, International Journal for Business Education, 160, 22 (2020)

30. T. Kromydas, Palgrave Commun, 3(1), 1 (2017)

31. G. Krücken, Beiträge zur Hoschschulforschung, 39, 10 (2017) 
32. Viola A. Larionova, Alexander V. Tolmachev, Evgeniy V. Sinitsyn, Tatiana Y. Bystrova, Paper Materials of the 1st China-Russian Scientific Readings «Urbanization Level, Rural Labor Transfer and Economic Growth in the XXI-st Century: Economic Models, New Technologies and Management Practices», dedicated to the 60th anniversary of Lanzhou University of Finance and Economics professor Galina V. Astratova and 20th anniversary of her scientific school "Theory, methodology and practice of marketing and marketing research" , 155 (2019)

33. Musselin Christine, Socio-Economic Review, 16(3), 657 (2018)

34. Evgeny V. Sinitsyn, Alexander V. Tolmachev, Alexander S. Ovchinnikov, Electronic Scientific Economic Journal, 6(3) (2020)

35. The Condition of Education 2020. Education Expenditures by Country. 2016. Chapter: 4. International Comparisons Section: Finances, https://nces.ed.gov/

36. Universities 2030: Learning from the Past to Anticipate the Future, Edited by Adam R. Nelson \& Nicholas M. Strohl (University of Wisconsin-Madison) (2014) https://globalhighered.wordpress.com/

37. Weimer Leasa. 10 trends changing global higher education. Policy \& Strategy. 26 July 2017, https://www.eaie.org/

38. World Development Report 2016: "Digital Dividends", https://unctad.org/

39. World Trade Report 2019. The future of services trade, https://www.wto.org/

40. World University Rankings 2021, https://www.timeshighereducation.com/

41. World University Rankings 2015-2016, https://www.timeshighereducation.com/

42. L. Yuan, S. Powell, J. Cetis, MOOCs and open education: Implications for higher education, JISC CETIS (2013)

43. 2017 Horizon Report (2017) https://library.educause.edu/ 